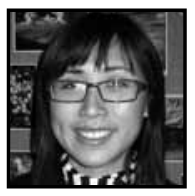

\title{
Sound Stories Cultivate Historic Empathy in Teachers and Students
}

\author{
Sumer Seiki
}

\section{ABSTRACT}

With the increased demand for culturally and linguistically relevant teaching, this paper explores the use of sound stories to cultivate empathetic understanding in undergraduate preservice teachers. I inquiry into the process of creating, writing, and performing a sound story about my family's American Japanese imprisonment experience to better understand this teaching method and adapt it for teacher education. The inquiry reveals counter stories of agency and resistance, as well as a powerful and creative teaching tool for increasing empathy in both the teacher and students.

\section{Justification: Personal, Practical, Social}

ast year I taught a new course and though I am not new to classroom teaching, I learned reflexively through the process of preparing and redesigning my teaching methods for a new student body and content. The course was the first of two required educational foundation classes for all education majors and minors, at our Midwestern United States liberal arts undergraduate teacher training program. Predominately freshman and sophomore students interested in becoming K-12 teachers enroll in this course, Social Justice and Education. In the course, we critically analyze the political, sociocultural, and economic forces that impact school policies and practices while also introducing them to the demands of teaching for social justice.

In preparation for the course, I reexamined the current and projected student demographics, which indicate ethnic minority populations within the United 
States steadily increased since the 1980s, and currently comprise over half of the total U.S. school age population (U.S. Census Bureau, 2011). Teacher demographics showed the predominance of non-minority teachers, a consistent trend for over thirty years (Torres, Santos, Peck, \& Cortes, 2004). Morell's (2010) research supports the previous findings indicating the majority of United States pre-service teachers do not share the same cultural or linguistic heritages as those of their students; they are predominately white and middle class. In fact, research revealed these pre-service teachers, demographically similar to my students, have shown a "shallow historical consciousness about race, racism, and conceptions of culture and White identity but also report discomfort discussing these things" (Sleeter, 2008 p. 121). It became clear through research and classroom discussions that a number of my students too felt uncomfortable discussing issues of race and would disengage through silence. I needed to prepare these preservice teachers to be conscious of the growing differences between home and school as well as teach students with cultural and linguistic practices different than their own, both important elements in teaching for social justice (CochranSmith et al., 2009; McAllister \& Irvine, 2002). This research preparation also uncovered an important step in cross-cultural teaching; teachers must learn to understand their own worlds and the worlds of their students (Gay, 2010). Once teachers understand their own cultural worlds, they are better able to empathetically enter into the worlds of their students (Sleeter, 2008; Lugones, 1987).

Grounded in demographical and background research, my emerging research puzzle began to form with the initial question of, "how can I improve my teaching methods to foster preservice teachers' understanding of their cultural worlds and empathetically conceptualize their students' worlds?" In this early stage of my investigation I turn to Sleeter (2010), an influential teacher educator, who also engaged in the process of deepening her predominately white pre-service and inservice students' critical understanding of history and personal culture. Sleeter knew the importance of building empathic understanding. She critically investigated five generations of her family life history. Tracking individual family members' lives she uncovered unknown roots in slavery and Appalachia revealing the economic, political, and social experiences of each member. She found unexpected ethnic origins "recover[ing] lost memories of blurred racial boundaries and reinvented origins, lost narratives of having both perpetrated and also having been victimized by racism" (Sleeter, 2008, p. 121). She discovered that her own personal critical life history exploration can "serve as an entrée" for pre-service teachers' understanding of "historical memory about race, ethnicity, and identity_revealing the ways in which power and privilege have been constructed, the prices people have paid for that, and the ways in which ordinary people have challenged inequities" (p. 115). In the same vein, she 
asks her pre-service teachers to inquire critically into their own family histories to personally contextualize their family members' "worlds." This critical life history research reveals the various subject positions within our family line/lives that have been covered over, and these lost stories serve to reveal institutionalized power relationships (Sleeter, 2008, 2010).

This lived inquiry and critical analysis cultivated, in both herself and her students, an understanding of their personal and generational "worlds." Through this process of critical analysis, Sleeter's family history research methods offered me the possibility of cultivating empathy in myself and in my preservice teachers, an essential skill in cross-cultural teaching (McAllister \& Irvine, 2002) and a structural component of understanding history (Cunningham, 2009). Nurturing empathetic and historic understandings were key components of my teaching goals and helped me to reform my research puzzle. I was intrigued by Sleeter's methods and suggestion to have teacher educators and preservice teachers "examine their own backgrounds and experiences to identify assumptions, beliefs, and values, as well as cultural contexts in which they grew up, which impact their understanding of schooling and students" ( $p$. 114). I decided to incorporate Sleeter's methods in my evolving research puzzle. With this addition, I sought to more clearly define and refine concepts involved in historic empathy.

\section{Empathy}

My teacher education empathy research revealed McAllister and Irvine's (2002) description of empathy as a learned skill that is both "affective and cognitive" in nature. Empathy is commonly referred to as the ability to identify the circumstances, values, thoughts, and emotions of another in order to understand the complexities of the other's life. Lugones (1987) describes this empathic attribute as the ability to world travel in loving perception or the ability to understand the feelings and perspective of another from the inside as well as understand the complex macro political and social forces impacting those perspectives. Noddings (1984) describes empathy as being one with the person in a non-judgmental posture. Examining and embodying the full form of empathy is a necessity for transforming traditional teaching practices into culturally responsive teaching, though not the sole requirement (Gay, 2010).

In her research, Cunningham $(2007,2009)$ described a group of history teachers cultivating students' empathy with their lessons, content, and interactions. 
Through her case study research, she shares a variety of strategies to motivate and build student empathy and identifies four parts to cultivating empathy. She argues that teaching empathy utilizes the abilities to "1) think/reason/puzzle out; 2) experiment/feel/sense/recreate/get into; 3) understand/grasp/see/know; and 4) imagine" (Cunningham, 2009, p. 689).

Using these process terms, Cunningham's teacher participants engaged in identifying and diagnosing the types of empathy skills students needed to learn. Then, based on the students' learning needs, these teachers drafted optimal lessons that also accounted for the student, structural, and teacher limitations. Cunningham's (2007) iterative teaching cycle of "observing, diagnosing, reflecting, refining, practicing, and experimenting anew" (p. 612) bolstered empathy through creating well-tailored lessons suited for the specific needs of students.

Wrestling with these definitions of empathy and intrigued by Cunningham's teaching cycle to cultivate student empathy, caused me to engage with Sleeter's $(2008,2010)$ critical family history teacher-education research in new ways. I thought about my prior undergraduate teaching experiences of cultivating empathy through using sound stories of my families experience with race-based imprisonment of American Japanese during World War II. I consider the possibilities of using those stories in the same bent as Sleeter and investigating the effectiveness of my method through Cunningham's cycle. I decide to reshape my research puzzle one last time; I focused on my teaching experiences using sound stories, a narrative art-based teaching method employing sound. I inquired into my teacher narratives through the lens of Sleeter's critical family history method as well as explore the potential of this method for increasing preservice teachers empathetic understanding of historic racism through Cunningham's cycle.

\section{Inquiry}

As I investigate my teaching and family history, I borrow from some narrative inquiry methods (Clandinin \& Connelly, 2000). Inspired by Cardinal (2011), in her autobiographical narrative inquiry, I too found this method offered me space to explore my narratives. Clandinin and Connelly's (2000) description of narrative inquiry as "strongly autobiographic" provides a vehicle to inquire into my previous method of teaching my critical family history through sound stories to cultivate empathy. 
Narrative inquiry helps me to begin to understand and unravel the complexities of my experiences. Since experience is both personal and social, and inherently connected to education, it is the study of life (Dewey, 1938). Narratives are the mechanism through which humans share their experiences because "humans are storytelling organisms who, individually and socially, lead storied lives" (Connelly \& Clandinin, 1990 , p. 2). Hence, understanding the narrative experience of my previous teaching is a way for me to understand and explore education as a complex human experience or phenomenon. Connelly and Clandinin (1990) describe looking through the lens of studying experience:

People shape their daily lives by stories of who they and others are and as they interpret their past in terms of these stories. Story, in the current idiom, is a portal through which a person enters the world and by which their experience of the world is interpreted and made personally meaningful. Viewed this way, narrative is the phenomenon studied in inquiry. (p. 477)

Dewey (1938) explains that empirically investigating personal experiences can hold the possibilities of enhancing educational practices, since education begets experience. Clandinin and Connelly (2000) characterize individual narratives as existing within a dynamic three-dimensional space: temporal, social, and place-based. The interplay occurs among the personal and social storied lives of educators, students, communities, institutions, policies, and researchers, a network of life threads and worlds intersecting and interweaving in a particular space and time. Thus, narratives of life experiences teach us about education. Clandinin and Connelly (1995) explore teacher narratives and reveal how teachers' conscious and unconscious knowledge was learned by experience and are expressed in their professional landscapes. I explore my own teacher narratives through my understandings of narrative inquiry to "articulate my emerging understandings" (Cardinal, 2011, p. 83) about using sound stories to tell my own family history.

Hence, I begin my examination of my own teacher narratives of cultivating empathy through the use of sound stories. I first learned this method through our informal drama group practice exercises; collectively we created and told a variety of humorous stories through sound. Becoming familiar with this drama technique, I knew I could translate it from drama class into history class as well as into K-12 classrooms.

A sound story, for this paper, is much like a traditional theater performance without visual senses; the audiences' eyes are closed. A sound story is explained 
through narration as the actors emote the personal experiences of their main characters. The setting of the scene is created by sound effects made by the performers through their bodies. Since sound transmits wave vibrations through the air impacting the listener, the sound story creates story images in the audience members' minds as they also physically experience the emotions.

Neuroscience research reveals that closing the eyes enhances listeners' emotional experience especially with regard to negative music sounds (Lerner, Papo, Zhdanov, Belozersky, \& Hendler, 2009). Similarly this performance produces many negative sounds and emotions due to the racial oppression content; therefore it stands to reason that as the audience closes their eyes during the performance they will experience an enhanced emotional effect as documented in the research of Lerner et al.

Engaging in this process of creating a sound story of my personal and family history, I relive these experiences through the retelling of these narratives. Paying attention to "the complexity of lives and experiences help[s] us understand them in deeper and more complex ways" (Clandinin et al., 2006). I find the "telling, retelling, and reliving" storied lives (Clandinin \& Connelly, 2000) is active reflection, leading me, the storyteller, and participants to "imagine" new possibilities (Huber \&Whelan, 1999).

To begin this inquiry, I explore my research texts, which were collected in an introductory undergraduate Asian American history course at a large researchbased California University. This course covered the historical experience of Asian Americans from 1840 to the present, which included American Japanese imprisonment as required content. While I was a teaching assistant for this course, I noticed a significant number of my students did not understand American Japanese imprisonment beyond the facts they memorized; they lacked empathetic understanding. For two years I worked with different professors teaching the course to cultivate student empathy around the required course topic of American Japanese imprisonment. My research data collection for this work includes field texts before and/or after the performances, drafts and finalized scripts, audiotaped in-class performances, and family annals. This research project is also part of a larger body of research on relational counter-hegemonic pedagogy with the informal performance group, which I participated in for five-years, 2006-2011 (Torres, 2010; Seiki, Torres, Ramirez, \& Carreon, 2010; Wilson et al., 2011).

The term American Japanese is used in this paper instead of Japanese American to acknowledge that the majority of those interned were United States citizens, 
including my family members (Chan, 1991). I also use American Japanese to challenge the dominant narrative notions of American Japanese as suspicious perpetual foreigners and to rightfully place their nationality first. I also use the term imprisonment in place of internment because I find it to be a more accurate depiction of my family's experience.

Below is the description of the final performance of my family's sound story in Asian American History class. I begin inquiring into the end of the story and work my way through the other research texts in order to fully investigate the research puzzle.

\section{A Moment}

The sound story ended. Scattered sniffles and heavy sadness filled the Asian American History class auditorium. Then silence. Two hundred students, a professor, four teaching assistants, the sound story performers, everyone, was still. As the audience kept their eyes closed, I breathed deeply, stepped forward, and requested that everyone open their eyes. As they looked up, I saw many had tears.

As one of their teaching assistants, I was a familiar face to them. I explained that the sound story I performed, with an informal performance troupe, was a story mostly based on my family's experience of American Japanese imprisonment during World War II. During the performance, the students' vague understanding of the personal nature of imprisonment suddenly transformed into living, breathing flesh before them. Our collective emotions were palpable, theirs and mine; I felt the barriers between all of us shatter. In that shared experience of sound storytelling, they were with me; they lived it themselves through waves of sound that transported them back into that historical time alongside my family.

No longer was imprisonment an abstract fact on a page. It became a reality as they experienced the real emotions and sounds of that time and moment, a powerful event across time and generations, touching them right now, through me. The empathy they initially lacked in their reading reflections and discussions transformed as they began to engage in heartfelt, emotional ways, gently asking questions about my family and their experiences. As I spoke to them about the people in the story-my father, uncle, grandmother, and grandfather-I saw them make deeper connections to the reality of imprisonment. No longer were the American Japanese imprisoned 
just distant analytical facts and figures. They were identifiable people-they were my family.

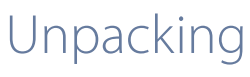

I use narrative inquiry to unpack this moment of student empathetic breakthrough in class as described above. With this method, I travel into the three-dimensional space of the moment to examine the temporality, sociality, and place (Clandinin \& Connelly, 2000). Analyzing this moment leads me to time travel backward and forward into the experiences of creating, rehearsing, and performing this particular sound story described below. I am led back into my set of field texts, scripts, audiotaped performances, and family annals. Each of these data pieces and description of my process leading up to the performance, help explain how this moment of transformation was created in each performance.

In each class performance, the student reaction was similar. However, the moment described above was my final performance in Asian American History class since I completed my graduation requirements and was transitioning out of graduate school. When I inquire into this moment I solely reference the data pertaining to this final performance. In the unpacking of the process leading up to the lesson, the analysis reveals the cultivation of empathy through sound story making and telling.

\section{Lesson Development}

As I inquire into this breakthrough moment, I am struck by the temporal shifting I take between the present moment in class, moving to the lives of my family during World War II in the performance, and back again to the present. These temporal shifts in time are analogous to my temporal process of understanding. As I analyze this temporal understanding process, I first travel back in time exploring my motivation for creating this lesson. My motivation for developing this sound story and engaging in the process of developing the lesson expanded my process of thinking, reasoning, imagining, and puzzling out my family's story. I gained insights as I wrote the script and thought about the learning needs of my students. I was in the initial stages of Cunningham's (2007) empathic teaching cycle, observing my students and diagnosing their empathetic learning needs. In focusing on my students' needs, I discovered new empathetic understandings. 
My interest with creating this lesson began after reading early assignments, listening to the discussion sections, and answering lecture questions. As I listened to students, I realized that American Japanese imprisonment was being treated like a fact to be memorized. But the human understanding of the experience and its brutality was missing; this disturbed me since the past often repeats without understanding. Cunningham's (2009) history teacher participants also gauged their students' inability to empathize through classroom interactions and assignments. Like me, these teachers creatively tailored and designed lessons to build the skill of empathy.

When designing the lesson, I first identified gaps in students' understanding. I was familiar with these gaps since I taught two discussion sections, read course papers, met regularly with fellow course facilitators, and attended every lecture. By using their course content knowledge, I chose specific elements for the sound story script. I was able to focus on bridging these gaps between the facts they knew and the empathetic understanding many were able to grasp. Noting various limiting factors, I chose the sound story as the best strategy for lesson delivery. The sound story technique was ideal for the two hundred-student lecture because it felt very personal. Yet it allowed each audience member emotional privacy. Additionally, the informal performance troupe was not anxious about performing in front of a large group since the audiences' eyes would be closed.

I began to draft the script, retelling and interweaving the stories and facts I heard while growing up. These included personal facts, like my grandmother being pregnant with my father and caring for my toddler uncle when she was forcibly removed from her home in San Francisco's Japantown. My grandparents owned an apartment building in this enclave and were forced to leave and move to a dirt-floor shack in Arizona. Their property would be lost forever. With these details, I constructed the framework of the story and started the script while they were home in San Francisco preparing to leave. Piecing these details together allowed me to imagine what each of my family members must have felt like and I, knowing each of their personalities, created suitable dialogue.

Once the base of the story was filled, I included the historical context of open hostility toward Japanese who were derogatorily referred to as "Japs." Signs of hostility were not only permissible in actions and words but also in storefront windows stating, "no Japs." With this historical context, I also included facts students learned in class, such as what happened on the warfront on the day my family members were removed from their home. Then I added the personal touches and family memories. 
I included one important memory of my grandmother. As a small child, I asked her if I could wear her kimono when I got married. She agreed but, after she went to look for it, she realized she no longer had it: she was forced to leave it behind with her many other possessions since she was only allowed an allotted number of bags to carry. The moment she realized it was gone, a brief moment of sadness took over her face, which she quickly replaced with a smile. She didn't want me to relive her pain and I never spoke of it again. Reverberations of pain from the past moved forward into that present moment; she wanted to protect me from the pain and I never wanted to cause her any more grief over the losses she experienced.

Once the script was completed, I presented the script to my fellow performers to achieve historical authenticity. Though they were not American Japanese a couple of troupe members were familiar with the facts surrounding imprisonment. Together they read through the script and we entered the three-dimensional lived landscape of my family. We thought about their experience in that day and created background noises appropriate for that time and space. We added walking sounds and details to the radio announcement of Executive Order 9066, and we discussed the emotional experiences of each of my family members. Connecting all of these sounds and setting an emotional tone, we together built the soundscape for my family's story. Through this process we engaged in the next steps of Cunningham's (2007) empathetic teaching cycle of reflecting on the draft script and refining it.

As I look back at the weaving of macro-level facts about wartime California impacting my own family memories, I know I as a teacher purposefully shared these personal facts to help students empathetically connect with this historic event. Similarly, Cunningham (2007) found her teachers designing lessons with the right proportion of content, emotion, and accessibility. Her research also showed that students enjoyed and learned from teachers who shared their own historically based marginalization stories. As I consider this moment, I realize that students' emotional reaction in my class was based in part on risking to share my personal family story.

I am reminded of the emotional journey I had to enter into in order to understand the part of empathy that requires us to affectively understand another's perspective. It was during performance rehearsals that I moved into the next steps of the empathy teaching cycle (Cunningham, 2007) of practicing the lesson and experimenting anew. It was in these parts of the process, described below, that I felt, recreated, and embodied the emotions within the sound story script. It was in these phases that I learned to empathetically connect at deeper and physical levels, which enabled me to share that new understanding with my students. 


\section{Rehearsing \& Performing}

During the performance rehearsals, I took on the role of my grandmother. As I read the lines, I could hear the intellectual understanding in my delivery but I couldn't convey the depth of emotion required. I wasn't fully entering the emotional world of my grandmother. I was reluctant. Yet I had an inner commitment to my grandmother pushing me to engage more authentically. Since I was not a professional actress and I needed help moving from just reading my lines to embodiment. I asked the drama teacher of the informal performance troupe, whom I had worked and become friends with for five years, to help me embody the words. She replied that to do so we must enter my grandmother's emotion through my body.

In our small practice room, she wrapped her arms around my torso and pulled me west. Another fellow performer put her hands on my shoulders, look down at me, and then also forcibly pushed me west. My feet began slipping. She pulled harder. The teacher directed me to push east, moving toward the door, while reciting my lines.

At first the words came only from my head, but then as I grew frustrated my voice dropped deep into my belly. They pushed and pulled my body harder and harder, and I tried to withstand the pressure and push more and more. I could feel the physical strain on my body, my muscles resisting and pushing back; I ached. Finally, I began to move beyond the barriers of hesitance and feel what my grandmother must have felt as I was finally able to embody her emotions. It was in that moment I realized how, with all her might, she struggled to protect her family, her toddler son, and unborn child, my father. I felt her physical and emotional strength, and I know she resisted. She was always strong. In that moment of both intellectually understanding the context and physically experiencing oppression, I began to embody my grandmother's strength as a powerful "agent of history" (Chan, 1991).

I could see the untold story of my grandmother's agency and her courageous choices to be a present and loving figure to her family. She sacrificed her own beloved possessions, her kimono and family photos, to prepare and pack the limited bags for the baby on the way, my father. I caught a mere glimpse of her beauty and the embodiment of frustration at the injustice of it all. It was during this exercise a new story was born: a story of Gaman, the cultural practice of a deep commitment to hope beyond seemingly unbearable circumstances and to embody patience and dignity despite current struggles (Hirasuna, 2005). My grandmother's story of Gaman was sacred because it remained a mostly unnoticed part of American history, yet it "lived, so to speak, in the arms and legs and bellies [of my family]... This story lay deep 
in the consciousness of the people" (Crites, 1971, p. 294). My grandmother's perseverance, a story of a strong Nisei, meaning second-generation American Japanese, protecting and sacrificing for her family, lived in my body and voice. During this place of embodiment, of historical empathy, I could see the stories of agency and learned to tell them from a new empathic understanding to my students.

It was this deeper understanding of my grandmother and the physical feeling of oppression in my body that I performed that day in Asian American History class. The empathetic emotions and perspectives that I gained in the rehearsals allowed me to fully engage with the students. I as a teacher had to learn alongside my students to cultivate my own empathy so they could learn anew. The risk I had to take as a teacher to fully embody my grandmother reminded me of Sleeter's (2008, 2010) discovery of her family's agency countering the racial hostility of the time. Both Sleeter and I find that modeling for students and preservice teachers our own critical personal investigation is a key component of teaching. We as teachers must first embark on our own journeys to model for our students the willingness to engage in their own teaching practice.

\section{Discussion}

Deconstructing the planning, rehearsal, and performance through narrative inquiry provided me the space to understand the process of using this sound story teaching method in a history class. Now, as I consider adapting this method to my new course, Social Justice and Education, I identify the essential elements I need to prepare as a teacher as well as how to prepare my students to engage with this method. Finally, I discuss the possible implications of using this method for teacher education and $\mathrm{K}-12$ classrooms.

I found the many preparations that I as a teacher had to go through to create the sound story lesson were essential to create the moment of deep empathetic understanding in class. My preparations followed the similar process that Cunningham (2007) described in her empathetic teaching cycle. I engaged in the process of observing my students, diagnosing their learning needs, and creating a lesson. As I created the lesson, which involved writing the script, I immersed myself in context details fully understanding with my intellect the historic situation. Additionally, digging into the storied lives of my family also unearthed lost stories of agency and strength similar to Sleeter's (2008) own discovery of agency in the complex lives of 
her family. Writing the script allowed me to understand the affective experience of my family members more fully. As I articulated and gave words to each of my family members' experiences, I learned to give voice to their strength, which cultivated empathy in myself through sound story making. My colleagues served as powerful witnesses and helped me to further polish the script with rich details while I also considered my students' learning needs.

During the rehearsal practice is when I as a teacher had to risk emotionally for empathetic embodiment. Though my students never knew of our rehearsal preparations, the time we spent together was crucial. We practiced telling and retelling the sound story. I grew. I learned as a granddaughter about my grandmother's "world" (Lugones, 1987). In the rehearsals I world traveled into the personal life of my grandmother, investigating her values and emotions, within the context of a hostile sociocultural, economic, political climate. Through risk taking, I more fully understood the strength she embodied. My understanding as a granddaughter impacted my understanding as a teacher. These "worlds" I inhabited through the roles of granddaughter and teacher began to inform one another and deepen my knowing (Lugones, 1987). Throughout the rehearsal we as a performance troupe were also cultivating trust in our practice. The relational trust we built helped us to rely on one another through the in-class performance.

Through the sound-storied performance, the last stage of the cycle, we shared our "world" knowledge. I offered to my students during the sound performance my new understanding. The sound waves I, and my fellow performers, emitted that day crossed many worlds, my worlds, the performers' worlds, and the students' worlds. We collectively came to understand my grandmother's story, my family's story, and the bigger story of American Japanese imprisonment. Our collective understanding was evident in the moment of transformation. "...Our stories do indeed vibrate across the web and impact in ways that I will never be able to comprehend" (Cardinal, 2011 p. 87).

Each of these steps I took as a teacher align with Cunningham's teaching cycle and help articulate the process I took in order to create the lesson. Cunningham (2007) describes the cycle as a method that develops students' empathy. However, I find this cycle helped me articulate the back-and-forth steps I took in order to develop my own empathy. Understanding this process allows me to better teach my students, as I develop a new sound story lesson for my new Social Justice and Education course. 
Understanding more of the teacher preparation process, I turn and focus on student preparation for sound story telling. First I consider my new course students, I think about their predominantly suburban and rural Midwestern cultural backgrounds, experiences, and values. I seek to understand their generational experiences different than my own. I also examine their ability as a group to handle emotion, and what they need to draw them into an empathetic understanding despite their resistance to exploring racial issues.

As I think about their resistance, I also consider my own struggle to experience the depth of oppression my grandmother lived during imprisonment. Perhaps in some ways my students' resistance is not unlike my own reluctance to fully experience the pain of racial oppression. My resistance however, was countered by my own commitment to represent my grandmother accurately. I also had strong relational bonds of trust with my informal performance troupe members, which we had built over five years. Both of these factors allowed me to explore on a deep emotional level. Unpacking this moment further and applying it to my new course, I realize I need to find ways to bridge the experiential gap for my students and make their engagement in this work personal. Additionally, I must cultivate trust with them so that they can engage on new levels of empathetic understanding. These empathetic learnings will better able to help them as they work with diverse students.

Through engaging in this cycle and sharing these critically researched stories creatively through sound, teacher educators, pre-service teachers, and K-12 classroom teachers can develop multiple forms of empathetic understanding in telling their or their students' critical family histories through the sound story medium. "Experiencing the multiple subject positions that each of us inhabits and the multiple subject positions open to us" (Sleeter, 2008, p. 122), we can explore alongside one another, together capturing the humanity and complexity of our worlds. Maxine Greene (1993) writes: “...to keep speaking, to keep articulating, to devise metaphors and images, as they feel their bodies moving, their feet making imprints as they move toward others, as they try to see through others' eyes" (p. 213).

This quote calls for more stories to be unearthed, stories of our students' and teachers' "worlds" (Lugones, 1987). Speaking these unknown and untold stories into existence in our preservice teacher and K-12 classrooms will create new understanding of their humanity, their bodies, their voices, their emotions, their family cultures and those that lived in another historical time and place. Together we can strive to see and be understood. Maxine Greene is inviting us into new possibilities where family history sound stories are a "world traveling" pedagogical strategy, which cultivates multiple forms of empathy in both teachers and students (Lugones). 


\section{References}

Cardinal, T. (2011). Stepping-stone or saving story? LEARNing Landscapes, 4(2), 79-92.

Chan, S. (1991). Asian Americans an interpretive history. Detroit: Twayne Publishers.

Clandinin, D. J., \& Connelly, F. M. (1995). Teachers' professional knowledge landscapes. New York: Teachers College Press.

Clandinin, D. J., \& Connelly, F. M. (2000). Narrative inquiry: Experience and story in qualitative research. San Francisco: Jossey-Bass.

Clandinin, D. J., Huber, J., Huber, M., Murphy, S., Murray Orr, A., \& Pearce, M. (2006). Composing diverse identities: Narrative inquiries into the interwoven lives of children and teachers. Oxon: Routledge.

Cochran-Smith, M., Shakman, K., Jong, C., Terrell, D., Barnatt, J., \& McQuillan, P. (2009). Good and just teaching: The case for social justice in teacher education. American Journal of Education, 115(3), 433-443.

Connelly, F. M., \& Clandinin, D. J. (1990). Stories of experience and narrative inquiry. Educational Researcher, 19(5), 2-14.

Crites, S. (1971). The narrative quality of experience. Journal of the American Academy of Religion, 39(3), 291-311.

Cunningham, D. L. (2007). Understanding pedagogical reasoning in history teaching through the case of cultivating historical empathy. Theory \& Research in Social Education, 35(4), 592-630.

Cunningham, D. L. (2009). An empirical framework for understanding how teachers conceptualize and cultivate historical empathy in students. Journal of Curriculum Studies, 41(5), 679-709.

Dewey, J. (1938). Experience and education. New York: Collier Books.

Gay, G. (2010). Culturally responsive teaching: theory, research, and practice ( $2 \mathrm{nd}$ ed.). New York: Teachers College Press.

Greene, M. (1993). Diversity and inclusion: toward a curriculum for human beings. Teachers College Record, 95(2), 211-221.
Hirasuna, D. (2005). The art of Gaman: Arts and crafts from the Japanese American internment camps 1942-1946. Berkeley: Ten Speed Press.

Huber, J., \& Whelan, K. (1999). A marginal story as a place of possibility: Negotiating self on the professional knowledge landscape. Teaching and Teacher Education, 15, 381-396.

Lerner, Y., Papo, D., Zhdanov, A., Belozersky, L., \& Hendler, T. (2009). Eyes wide shut: Amygdala mediates eyes-closed effect on emotional experience with music. PLos ONE, 4(7), e6230.

Lugones, M. (1987). Playfulness, "world"-travelling, and loving perception. Hypatia, 2(2), 3-19.

McAllister, G., \& Irvine, J. J. (2002). The role of empathy in teaching culturally diverse students. Journal of Teacher Education, 53(5), 433-443.

Morell, J. (2010). Teacher preparation and diversity: When American pre-service teachers aren't white and middle class. International Journal of Multicultural Education, 12(1), 1-17.

Noddings, N. (1984). Caring: A feminine approach to ethics and moral education. Los Angeles: University of California Press.

Seiki, S., Torres, D. T, Ramirez, L., \& Carreon, O. (2010). Transforming graduate education through performance-based innovation. Paper presented at American Educational Research Association Annual Conference, Denver, CO.

Sleeter, C. (2008). Critical family history, identity, and historical memory. Educational Studies, 43(2), 114-124.

Sleeter, C. (2010). Becoming white: Reinterpreting a family story by putting race back into the picture. Paper presented at American Education Research Association Annual Conference, Denver, CO.

Torres, D. T. (2010). Transforming graduate education through performance. Unpublished practicum paper, University of California Davis, Davis, CA. 
Torres, J., Santos, J., Peck, N. L., \& Cortes, L. (2004). Minority teacher recruitment, development \& retention. Providence, RI: The Education Alliance at Brown University. Retrieved from http://www.alliance. brown.edu/pubs/minority_teacher/

U.S. Census Bureau. (2011). "School enrollment in the United States: 2009." Retrieved from https://www.census.gov/newsroom/ releases/archives/education/cb11tps04. html
Wilson, M.F., Torres, D., Seiki, S., Ramirez, L., Holmes, K., \& Watson Gegeo, K.A. (2011). Creating and Being the 'We': A Relational Counter-Hegemonic Pedagogy in a Graduate School of Education. Paper presented at American Education Research Association Annual Conference, New Orleans, Louisiana.

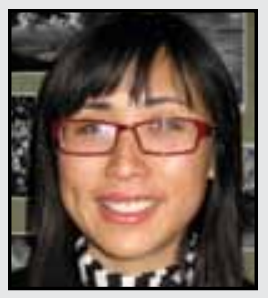

Sumer Seiki recently joined the Educational Studies Faculty at a Midwestern liberal art college. She obtained her $\mathrm{PhD}$ in Education and Masters of Science in Plant Biology at the University of California. Sumer's current research explores Asian American teacher narratives and relational counter hegemonic pedagogies within education. She teaches several courses including: social justice in education, science methods, cultural diversity, and educational inquiry. 